\title{
Correction to: A new 3D printing porous trabecular titanium metal acetabular cup for primary total hip arthroplasty: a minimum 2-year follow-up of 92 consecutive patients
}

Xiao Geng, Yang Li, Feng Li, Xinguang Wang, Ke Zhang, Zhongjun Liu and Hua Tian*

Correction to: J Orthop Surg Res 15, 383 (2020)

https://doi.org/10.1186/s13018-020-01913-1

Following publication of the original article [1], at the request of the copyright holder of the image in the bottom right panel of Fig. 2, the authors have replaced this figure with the following figure:

The original article has been corrected.

Published online: 26 November 2020

\section{Reference}

1. Geng $X$, et al. A new 3D printing porous trabecular titanium metal acetabular cup for primary total hip arthroplasty: a minimum 2-year followup of 92 consecutive patients. J Orthop Surg Res. 2020;15:383. https://doi. org/10.1186/s13018-020-01913-1.

The original article can be found online at https://doi.org/10.1186/s13018020-01913-1.

* Correspondence: zjliu@bjmu.edu.cn

Department of Orthopaedics, Peking University Third Hospital, No. 49 North, Garden Road, Beijing 100191, China

(c) The Author(s). 2020 Open Access This article is licensed under a Creative Commons Attribution 4.0 International License, which permits use, sharing, adaptation, distribution and reproduction in any medium or format, as long as you give appropriate credit to the original author(s) and the source, provide a link to the Creative Commons licence, and indicate if changes were made. The images or other third party material in this article are included in the article's Creative Commons licence, unless indicated otherwise in a credit line to the material. If material is not included in the article's Creative Commons licence and your intended use is not permitted by statutory regulation or exceeds the permitted use, you will need to obtain permission directly from the copyright holder. To view a copy of this licence, visit http://creativecommons.org/licenses/by/4.0/ The Creative Commons Public Domain Dedication waiver (http://creativecommons.org/publicdomain/zero/1.0/) applies to the data made available in this article, unless otherwise stated in a credit line to the data. 


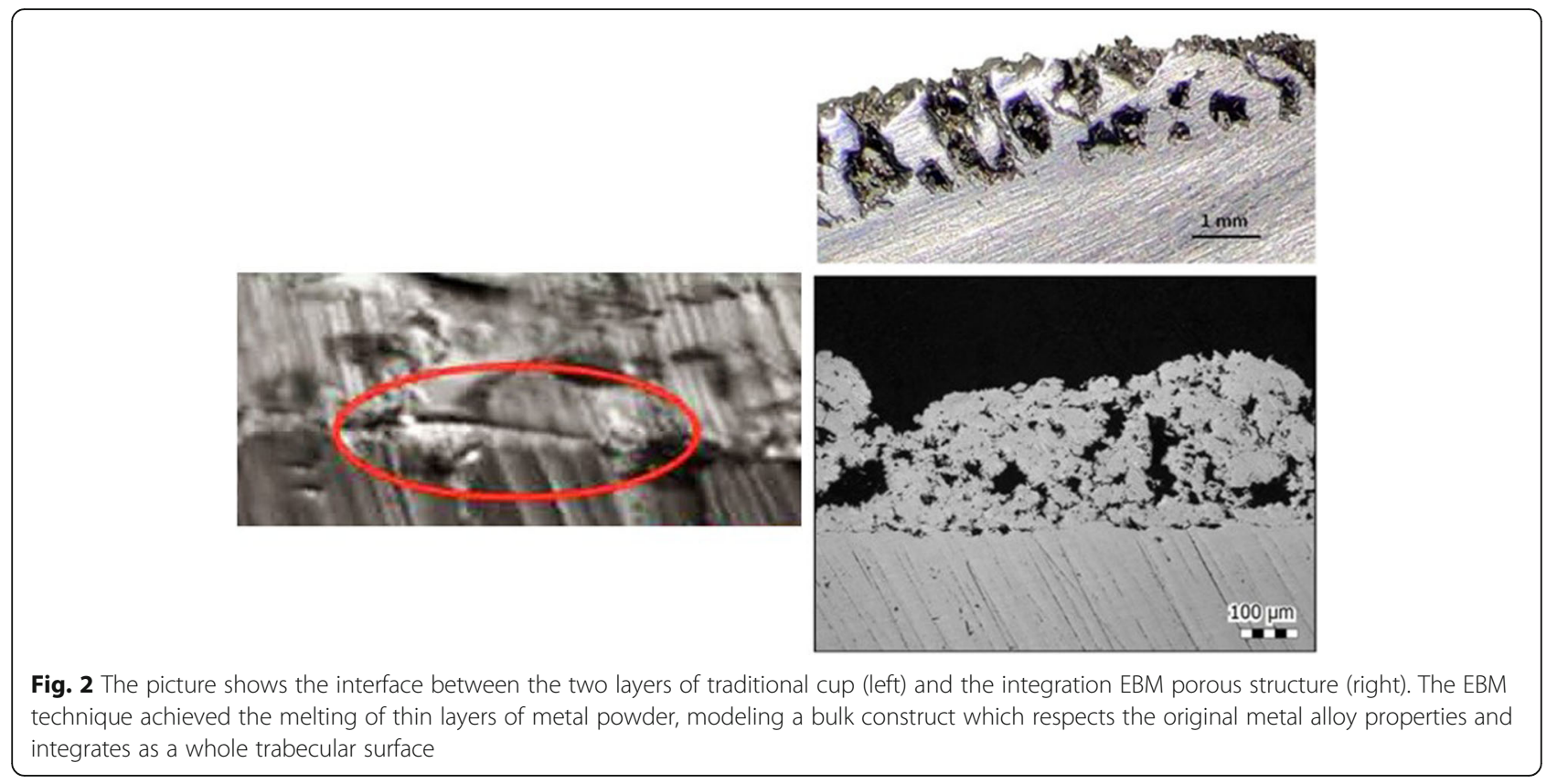

